\title{
Germination response of alder and birch seeds to applied gibberellic acid and priming treatments in combination with chilling
}

\author{
Norberto DE ATRIP, Conor O’REILLY* \\ UCD School of Biology and Environmental Science, UCD College of Life Sciences, University College Dublin, Belfield, Dublin 4, Ireland
}

(Received 20 April 2006; accepted 13 December 2006)

\begin{abstract}
The effects of seed moisture content (MC), gibberellic acid $\left(\mathrm{GA}_{3}\right)$ concentration, chilling and priming pretreatments on the germination of common alder (Alnus glutinosa) and downey birch (Betula pubescens) seeds were examined. After treatment, the seeds were allowed to germinate for 42 days at $15{ }^{\circ} \mathrm{C}$ or $20^{\circ} \mathrm{C}$ (dark) $/ 30{ }^{\circ} \mathrm{C}$ (light). Treatment responses were similar at both temperatures and in both species. $\mathrm{GA}_{3}$ treatment of seeds in fully imbibed (FI) state for 30 days, or at the lower, target moisture content (TMC) for 30-90 days, significantly improved germination, but longer treatment periods reduced it (FI seeds) or had no effect (TMC seeds). Priming for two days improved germination in the FI seeds, but more than 4 days reduced it. Priming for up to 14 days had little effect on the germination of the TMC seeds.
\end{abstract}

alder / birch / seed / $\mathbf{G A}_{3}$ / priming

Résumé - Réponse germinative des graines de l'aulne glutineux et du bouleau pubescent à l'application d'acide gibbérellique et de traitements d'amorçage en combinaison avec du froid. Les effets de l'humidité des graines $(\mathrm{MC})$, de la concentration en acide gibbérellique $\left(\mathrm{GA}_{3}\right)$, du froid et des prétraitements d'amorçage sur la germination des graines d'Alnus glutinosa et de Betulus pubescens ont été examinés. Après traitement, les graines ont été mise à germer pour 42 jours à $15{ }^{\circ} \mathrm{C}$ ou $20^{\circ} \mathrm{C}$ (à 1 'obscurité) $/ 30{ }^{\circ} \mathrm{C}$ (à la lumière). Les réponses au traitement ont été similaires aux deux températures et pour les deux espèces. Le traitement, par $\mathrm{GA}_{3}$, des graines totalement imbibées (F1) pour 30 jours, ou de façon moindre, l'objectif d'humidité (TMC) pour 30-90 jours, ont amélioré significativement la germination, mais des périodes de traitements plus longues l'ont diminuée (graines F1) ou n'ont pas eu d'effet (graines TMC). Un amorçage de deux jours améliore la germination pour les graines F1, mais un amorçage de plus de 4 jours la diminue. Un amorçage jusqu'à 14 jours a eu peu d'effet sur la germination des graines TMC.

Alnus glutinosa / Betula pubescens / graine / GA3 / amorçage

\section{INTRODUCTION}

There has been a large increase in the planting of broadleaf species, such as common alder (Alnus glutinosa) and downey birch (Betula pubescens), in Ireland and other European countries in recent years. For this reason, there has been a renewed interest in examining all phases of nursery culture and seed ${ }^{1}$ factors with a view to improving yields in the nursery. Seeds of alder and birch often germinate poorly in the nursery, perhaps in part because of dormancy problems [40,41]. Moist chilling (ca $0-5{ }^{\circ} \mathrm{C}$ ) for $4-8$ weeks usually releases dormancy in seeds of both species $[19,39]$, but there is little information on the effect of applied growth regulators on dormancy release and the germination response in these species. Seeds can also be primed to stimulate germination, but the exact mechanism of this response is not understood [13]. Priming usually involves incubating seeds in a warm environment for a short period before sowing.

* Corresponding author: Conor.oreilly@ucd.ie

${ }^{1}$ The 'seeds' of alder and birch are actually winged fruits (achenes) that contain a single seed without endosperm that is surrounded by a pericarp.
Endogenous factors, especially plant growth regulators, such as gibberellins (GAs) (usually $\mathrm{GA}_{3}$ ) and abscissic acid (ABA) play a key role in the dormancy response mechanism in most tree seeds $[3,28,35]$. Dormant seeds of many tree species contain $\mathrm{ABA}$ in the embryonic axis, which prevents embryo growth [5]. However, embryo dormancy can be broken in hazelnuts (Corylus avellana) by exogenous $\mathrm{GA}_{3}$ or indirectly by applying treatments that result in the synthesis of endogenous GA, such as chilling [6]. Chilling appears to change the inhibitor - promoter balance in the seeds, suggesting that the requirement for moist chilling cannot be replaced entirely by exogenous GA application. However, additional $\mathrm{GA}_{3}$ might reduce the chilling requirement to release dormancy $[35,44]$. For this reason, a combination of chilling and $\mathrm{GA}_{3}$ treatments have been used to improve germination in a range of tree species [27].

Seeds of alder and birch are normally chilled in their fully imbibed (FI) state (ca 50\%-60\% moisture content; $\mathrm{MC}$ ) to release dormancy, but lower seed MC levels may be preferable. Seeds of these species can be adjusted to about 30-35\% MC and then chilled for 12-18 weeks to release dormancy and maximise germination speed [9]. Seeds adjusted to these 'target' MC (TMC) levels can be held at chilling or freezing 
Table I. Provenance details for seed lots of alder and birch used in study.

\begin{tabular}{llccc}
\hline Species & \multicolumn{1}{c}{ Country, seed zone and origin coordinates } & Seed lot code \\
\hline Alder & Southwest Scotland, origin unknown & $01(203) \mathrm{K}$ & $56^{\circ} 28^{\prime} \mathrm{N}, 3^{\circ}$ 0' $\mathrm{W}$ & AC-UK203-B104 $^{\mathrm{a}}$ \\
& Mideastern England, origin unknown & $01(403) \mathrm{F}$ & $52^{\circ} 22^{\prime} \mathrm{N}, 2^{\circ}$ 43' W & AC-UK403-B106 \\
\hline Birch & Co. Laois, Ireland & $00(417)$ & $53^{\circ} 02^{\prime} \mathrm{N}, 7^{\circ} 17^{\prime} \mathrm{W}$ & BC-IELAO-A20 \\
& Co. Cork, Ireland & $00(417)$ & $51^{\circ} 54^{\prime} \mathrm{N}, 8^{\circ} 8^{\prime} \mathrm{W}$ & BC-IECORK-A62 \\
\hline
\end{tabular}

a Abbreviated (last four digits) of code (supplier's tracking code) is in bold text.

Table II. Physical and germination (\%) characteristics $^{\mathrm{a}}$ of the alder and birch seed lots used in the study.

\begin{tabular}{|c|c|c|c|c|c|c|c|}
\hline \multirow[t]{2}{*}{ Species } & \multirow[t]{2}{*}{ Seed lot identity code ${ }^{\mathrm{c}}$} & \multirow[t]{2}{*}{ Moisture content (\%) } & \multirow[t]{2}{*}{ Purity (\%) } & \multirow[t]{2}{*}{1000 seed weight $(\mathrm{g})$} & \multirow[t]{2}{*}{ Viable seeds $\left(\mathrm{kg}^{-1}\right)$} & \multicolumn{2}{|c|}{ Germination $^{\mathrm{b}}$} \\
\hline & & & & & & $20 / 30^{\circ} \mathrm{C}$ & $15^{\circ} \mathrm{C}$ \\
\hline \multirow[t]{2}{*}{ Alder } & B104 & 11.6 & 90 & 1.44 & 443624 & 56 & 26 \\
\hline & B106 & 10.6 & 91 & 1.71 & 294149 & 59 & 9 \\
\hline \multirow[t]{2}{*}{ Birch } & A 20 & 11.3 & 56 & 0.620 & 368000 & 26 & na \\
\hline & A62 & 13.6 & 50 & 0.453 & 302000 & 15 & na \\
\hline
\end{tabular}

a All treatments/ observations carried out according to International Seed Testing Association rules by the Dept. of Agriculture, Abbotstown, Co. Dublin, Ireland.

${ }^{\text {b }}$ Germination at $20 / 30{ }^{\circ} \mathrm{C}$ and at $15{ }^{\circ} \mathrm{C}$ for non-pretreated seeds.

${ }^{\mathrm{c}}$ Abbreviated code (see Tab. I); na = not available.

temperatures for lengthy periods without the risk of premature germination $[9,10]$. A combination of $\mathrm{GA}_{3}$ and chilling at TMC levels might increase germination potential while reducing the risk of premature germination in alder and birch seeds. However, there is a paucity of information on the effect of $\mathrm{GA}_{3}$ and seed $\mathrm{MC}$ on the germination response of alder and birch seeds.

Tree seeds can also be primed at $15-20{ }^{\circ} \mathrm{C}$ for short periods (usually 7-21 days) to improve germination [4]. This treatment may invigorate or 'prime' the metabolic activity necessary to prepare the seed for germination, but if water availability is restricted, the radicle will not emerge [16,33]. Although seeds can be primed in the FI state, a lower seed MC level (e.g. TMC) will reduce the risk of premature germination and/or deterioration. However, the risk of premature germination can also be reduced if moisture uptake during priming is controlled using an osmoticum, such as polyethylene glycol (PEG) [14]. Primed seeds can generally tolerate post-sowing environmental stresses better than non-primed seeds [37]. This is usually reflected in higher germination and/or a faster rate of germination of primed compared with non-primed seeds $[4,8]$. However, the seeds of many tree species require chilling to release dormancy before they can germinate [18], so the effect of priming might be expected to vary with dormancy intensity prior to priming.

The objective of this study was to determine the effect of $\mathrm{GA}_{3}$ concentration during chilling on dormancy release in FI and TMC seeds of alder and birch. In addition, the effect of priming at $15^{\circ} \mathrm{C}$ with or without PEG on the germination response of FI and TMC seeds without $\mathrm{GA}_{3}$ was examined.

\section{MATERIALS AND METHODS}

\subsection{Seed material}

Two seed lots each of alder and birch provided by the Coillte National Seed Centre (Carlow, Ireland) were used in this study (Tab. I), which was carried out in 2003 . The seeds were stored at $4 \pm 1{ }^{\circ} \mathrm{C}$ before the treatments commenced. The physical and germination characteristics of the seed lots, based upon the official test results carried out elsewhere, are given in Table II.

\subsection{Experiment 1. Chilling, seed $\mathrm{MC}$ and $\mathrm{GA}_{3}$ treatments}

Some seeds were fully imbibed (about 50\% and 53\% MC in alder and birch, respectively) for treatment, as used in standard operational practice, while others were adjusted to TMC levels (Tab. III). The TMC levels (30\% and 35\% MC in alder and birch, respectively) were determined in previous research [9]. A measured quantity (weight basis) of distilled water or $\mathrm{GA}_{3}$ solution $\left(20 \% \mathrm{GA}_{3}\right.$ Powder; SuperGrow, LaSalle, Quebec, Canada) was added to the seeds of each species to adjust their moisture content to FI or TMC levels [30,38]. The FI seeds were treated in 0 (control), 100 or $200 \mathrm{ppm} \mathrm{GA}_{3}$ solutions. The TMC seeds received the same total amount of $\mathrm{GA}_{3}$ as the FI seeds, so higher concentrations of $\mathrm{GA}_{3}$ solution were used (since the total amount of solution absorbed is smaller). The seeds were then placed in loosely tied plastic bags in a refrigerator at $4 \pm 1{ }^{\circ} \mathrm{C}$ (in the dark) and stored for $0,15,30,60,90$ or 120 days. The seed to air volume ratio was about 1:4. The bags were shaken once weekly to prevent an accumulation of water/ solution at the bottom of the bags. 
Table III. Summary description of treatments applied to alder and birch seeds in the experiments. The seed lot and seed moisture content treatments were the same in both experiments. Experiment 1: Gibberellic acid treatments. Experiment 2: Priming with or without polyethylene glycol (PEG).

\begin{tabular}{|c|c|c|c|}
\hline Experiment & Treatment & Treatment description & Number of levels \\
\hline \multirow{3}{*}{1,2} & Species & Alder and birch & 2 \\
\hline & Seed lot & See Table I & 2 \\
\hline & Seed moisture content $(\%)$ & Fully imbibed or target moisture content & 2 \\
\hline \multirow{2}{*}{1} & Chilling & $0,15,30,60,90$ or 120 days & 6 \\
\hline & Gibberellic acid concentration & 0,100 or $200 \mathrm{ppm}$ & 3 \\
\hline \multirow{3}{*}{2} & Chilling & 0,9 or 18 weeks & 3 \\
\hline & Priming at $20^{\circ} \mathrm{C}$ : without PEG & $0,2,4,7$ or 14 days & 5 \\
\hline & with PEG & $0,4,7,21$ or 42 days & 5 \\
\hline
\end{tabular}

\subsection{Experiment 2. Priming with or without polyethylene glycol}

Seeds of each species were adjusted to FI or TMC levels using distilled water (without $\mathrm{GA}_{3}$ ) and then chilled in loosely tied plastic bags in a refrigerator for 0,9 or 18 weeks, in an identical manner to that described for experiment 1 . After chilling, half of the seeds were primed at $20^{\circ} \mathrm{C}$ in the dark for $0,2,4,7$ or 14 days, while the other half was primed in PEG solution under identical conditions for $0,4,7,21$ or 42 days (Tab. III). Since PEG reduced the risk that the FI seeds would germinate prematurely, longer periods of treatment could be evaluated. The seeds were placed on top of a germination paper saturated with a PEG-6000 solution at $0 \mathrm{MPa}$ (control), $-1.50 \mathrm{MPa}$ (alder) or $-1.0 \mathrm{MPa}$ (birch). The results of preliminary tests, using PEG solutions that gave osmotic potential from 0 to $-2.0 \mathrm{MPa}$, indicated that the selected concentrations would prevent radicle emergence.

\subsection{Germination tests}

The seeds were germinated in $12 \times 8 \times 5 \mathrm{~cm}$ transparent, rectangular plastic boxes (Hofstätter \& Ebbesen $\mathrm{A} / \mathrm{S}$, model 500/50, Espergærde, Denmark) each containing one germination paper (Frisenette Aps, No. AGF 725, $11.5 \times 7.5 \mathrm{~cm}$, Ebeltoft, Denmark). The germination paper was kept continuously moist through a filterpaper wick to the water reservoir in the box (containing approximately $150 \mathrm{~mL}$ distilled water).

Germination was assessed in both experiments over a 42-day period at a constant $15^{\circ} \mathrm{C}$ with $8 \mathrm{~h}$ lighting $\left(32 \mu \mathrm{mol} \mathrm{m} \mathrm{m}^{-2} \mathrm{~s}^{-1}\right.$; Philips TL-D $15 \mathrm{~W} / 83$ ) per day and at $20{ }^{\circ} \mathrm{C}$ (dark)/ $30{ }^{\circ} \mathrm{C}$ (light) with the same lighting and other conditions and close to $100 \%$ relative humidity inside the boxes. Dormancy is not normally expressed at the higher test temperature in both species [9]. The germination cabinet (CMC Germination Cabinet 400L D/N-L, Glesborg, Denmark) contained four replications per treatment combination. A replicate was a germination box containing approximately $0.15 \mathrm{~g}$ (alder) and $0.05 \mathrm{~g}$ (birch) seeds, which was equivalent to about 50 to 100 seeds in both species. The number of seeds that germinated prematurely was determined before the boxes were placed in the germinators; these values were excluded from the germination data (except where otherwise stated). Thereafter, the number of seeds that germinated was recorded every 3 or 4 days. A seed was considered to have germinated in either species when the radicle protruded about $2 \mathrm{~mm}$. Percentage germination and mean germination time (MGT) were calculated from these data. MGT was calculated as the mean number of days for the seeds to germinate [26]. If no seeds germinated, MGT was assumed to be 42 days to permit analysis of variance [24].

\subsection{Data analyses}

\subsubsection{Experiment 1. Applied $\mathrm{GA}_{3}$}

The data were analysed according to a full factorial ANOVA design to test for the effects of seed lot, $\mathrm{MC}, \mathrm{GA}_{3}$ concentration, chilling duration, germination temperature and their interactions on percentage germination and MGT using the GLM procedure in SAS [36]. Full factorial ANOVAs were carried out separately also on the data for each test temperature. Means were compared further using least significant means tests.

\subsubsection{Experiment 2. Priming}

The effects of seed lot, MC, PEG, chilling duration, priming duration, germination temperature and their interactions on percentage germination and MGT were evaluated using treatment durations $(0,4$ and 7 days) that were common to both the PEG and non-PEG treatments using the GLM procedure in SAS [36]. In addition, four full factorial ANOVAs were carried out to test for the effects of seed lot, MC, chilling duration, priming duration and their interactions on percentage germination and MGT, each carried out separately for one of the four data sets, i.e. with PEG or without PEG at each test temperature.

\section{RESULTS}

Treatment effects were clearer at $15{ }^{\circ} \mathrm{C}$ than at $20 / 30^{\circ} \mathrm{C}$, although the trend was similar at both temperatures. The data for $15^{\circ} \mathrm{C}$ only are presented for this reason. However, seeds germinated more rapidly at $20 / 30{ }^{\circ} \mathrm{C}$ than at $15^{\circ} \mathrm{C}$. Germination was generally much higher in alder than in birch, but treatment effects were generally consistent in each species. Birch lots normally contain a large number of empty and dead seeds, so germination was considered acceptable when more than $20 \%$. The response to treatment was small for seeds of both species that received no chilling, so most of the data for 0 chilling are not shown. 
Table IV. ANOVA of the effects of seed lot, seed moisture content, gibberellic acid concentration, and chilling duration on germination and mean germination time (MGT) of alder and birch seeds germinated at $15^{\circ} \mathrm{C}$. Values in bold are significant at $p<0.05$.

\begin{tabular}{|c|c|c|c|c|c|c|c|c|c|}
\hline \multirow[b]{3}{*}{ Source of variation } & \multirow[b]{3}{*}{ df } & \multicolumn{4}{|c|}{ Alder } & \multicolumn{4}{|c|}{ Birch } \\
\hline & & \multicolumn{2}{|c|}{ Germination } & \multicolumn{2}{|c|}{ MGT } & \multicolumn{2}{|c|}{ Germination } & \multicolumn{2}{|c|}{ MGT } \\
\hline & & $\mathrm{F}$ & $\mathrm{P}$ & $\mathrm{F}$ & $\mathrm{P}$ & $\mathrm{F}$ & $\mathrm{P}$ & $\mathrm{F}$ & $\mathrm{P}$ \\
\hline Seed lot (S) & 1 & 6.2 & 0.0139 & 5.5 & 0.0204 & 254.6 & 0.0001 & 12.0 & 0.0006 \\
\hline Moisture content (M) & 1 & 24.6 & 0.0001 & 75.8 & 0.0001 & 1.9 & 0.1701 & 31.3 & 0.0001 \\
\hline Gibberellic acid (G) & 2 & 17.8 & 0.0001 & 141.9 & 0.0001 & 39.7 & 0.0001 & 30.6 & 0.0001 \\
\hline Chilling (C) & 5 & 298.9 & 0.0001 & 482.4 & 0.0001 & 370.4 & 0.0001 & 370.0 & 0.0001 \\
\hline $\mathrm{S} \times \mathrm{M}$ & 1 & 3.7 & 0.0574 & 5.5 & 0.0198 & 1.4 & 0.2407 & 1.1 & 0.2941 \\
\hline $\mathrm{S} \times \mathrm{G}$ & 2 & 0.5 & 0.5941 & 8.4 & 0.0003 & 1.7 & 0.1857 & 0.2 & 0.8404 \\
\hline $\mathrm{S} \times \mathrm{C}$ & 5 & 7.3 & 0.0001 & 9.7 & 0.0001 & 9.1 & 0.0001 & 3.0 & 0.0114 \\
\hline $\mathrm{M} \times \mathrm{G}$ & 2 & 24.4 & 0.0001 & 6.3 & 0.0023 & 7.5 & 0.0007 & 1.8 & 0.1700 \\
\hline $\mathrm{M} \times \mathrm{C}$ & 5 & 89.3 & 0.0001 & 48.6 & 0.0001 & 78.6 & 0.0001 & 10.2 & 0.0001 \\
\hline $\mathrm{G} \times \mathrm{C}$ & 10 & 18.5 & 0.0001 & 15.3 & 0.0001 & 15.7 & 0.0001 & 10.8 & 0.0001 \\
\hline $\mathrm{S} \times \mathrm{M} \times \mathrm{G}$ & 2 & 0.5 & 0.5905 & 9.2 & 0.0002 & 0.9 & 0.4196 & 0.6 & 0.5790 \\
\hline $\mathrm{S} \times \mathrm{M} \times \mathrm{C}$ & 5 & 3.9 & 0.0019 & 6.2 & 0.0001 & 2.8 & 0.0190 & 1.2 & 0.3366 \\
\hline $\mathrm{S} \times \mathrm{G} \times \mathrm{C}$ & 10 & 4.3 & 0.0001 & 4.7 & 0.0001 & 1.6 & 0.0979 & 1.6 & 0.1169 \\
\hline $\mathrm{M} \times \mathrm{G} \times \mathrm{C}$ & 10 & 10.5 & 0.0001 & 9.4 & 0.0001 & 9.5 & 0.0001 & 9.1 & 0.0001 \\
\hline $\mathrm{S} \times \mathrm{M} \times \mathrm{G} \times \mathrm{C}$ & 10 & 3.5 & 0.0003 & 4.5 & 0.0001 & 1.1 & 0.3666 & 0.6 & 0.8043 \\
\hline Error & 216 & & & & & & & & \\
\hline Total & 287 & & & & & & & & \\
\hline
\end{tabular}

\subsection{Seed lot effects}

Seed lot effects on germination and MGT were highly significant in both experiments (Tabs. IV and V). The effect was particularly large in birch; germination was much higher in lot A20 than in lot A62. Seed lot also interacted significantly with other factors. For example, the interaction of seed lot with chilling and $\mathrm{GA}_{3}$ was significant, which reflected the fact that the seeds of one lot reached their maximum germination and lowest MGT following shorter durations of treatment and lower $\mathrm{GA}_{3}$ concentration than in the other lot. Because seed lot effects were generally consistent in both experiments and in both species, they are not described further.

\subsection{Experiment 1. Applied GA 3}

Chilling duration, $\mathrm{MC}$ and $\mathrm{GA}_{3}$ treatment and their interactions had a highly significant effect on germination and MGT in both species (Tab. IV). For clarity of presentation, only the data for 30, 90 and 120 days are shown (Fig. 1). Seeds given these treatments displayed the largest difference in the germination response to treatment. Few seeds given 0 days $\mathrm{GA}_{3}$ treatment germinated in either species.

Although $\mathrm{GA}_{3}$ reduced the chilling requirement, it could not fully replace it. The response to treatment was similar in both species, with chilling and $\mathrm{GA}_{3}$ treatment having a larger effect in birch than in alder. Germination was particularly low in birch seeds that received 30 days chilling without $\mathrm{GA}_{3}$. The response to $\mathrm{GA}_{3}$ treatment varied with seed MC.
The FI seeds given 30 days chilling germinated well in both species, but the effect of $\mathrm{GA}_{3}$ concentration was small. Germination increased from $49 \%$ (control) to $61 \%$ (100 ppm) and $64 \%$ (200 ppm) in the FI seeds of alder given 30 days chilling. The equivalent values were 16, 25 and $26 \%$ in birch. However, longer periods of chilling and $\mathrm{GA}_{3}$ treatment reduced germination in the FI seeds of both species. For example in alder prechilled for 90 days, germination declined from $51 \%$ (control) to $33 \%$ (100 ppm) and 36\% (200 ppm). A high proportion of these seeds germinated prematurely.

In contrast to the FI seeds, short periods of chilling were not effective in releasing dormancy in the TMC seeds, but $\mathrm{GA}_{3}$ helped to compensate for chilling. Following 30 days $\mathrm{GA}_{3}$ at TMC levels, seed germination increased significantly from $8 \%$ (no $\mathrm{GA}_{3}$ ) to $14 \%$ (100 ppm $\left.\mathrm{GA}_{3}\right)$ and $20 \%\left(200 \mathrm{ppm} \mathrm{GA}_{3}\right)$ in birch, but the response was small and not significant in alder. Following 90 days treatment at TMC levels in alder, germination increased significantly from $52 \%\left(0 \mathrm{GA}_{3}\right)$ to $67 \%(100$ ppm $\mathrm{GA}_{3}$ ) and $64 \%$ (200 ppm $\mathrm{GA}_{3}$ ). The equivalent values for the TMC seeds in birch seeds given 90 days chilling were $17 \%, 22 \%$ and $27 \%$. However, it appears that 120 days chilling without $\mathrm{GA}_{3}$ sufficiently released dormancy in alder (62\%) and birch (27\%) TMC seeds, with little further increase due to the applied $\mathrm{GA}_{3}$.

The pattern of response to treatment for speed of germination (MGT) was generally consistent with that observed for percentage germination in both species (insets, Fig. 1). The concentration of $\mathrm{GA}_{3}$ had a relatively small effect on the response. Germination speed increased greatly in seeds of both species given 30 days chilling at both seed MC levels, the 
Table V. ANOVA of the effects of seed lot, seed moisture content, chilling and priming duration on germination and mean germination time (MGT) of alder and birch seeds. Values in bold are significant at $p<0.05$.

\begin{tabular}{|c|c|c|c|c|c|c|c|c|c|}
\hline \multirow[b]{3}{*}{ Source of variation } & \multirow[b]{3}{*}{ df } & \multicolumn{4}{|c|}{ Alder } & \multicolumn{4}{|c|}{ Birch } \\
\hline & & \multicolumn{2}{|c|}{ Germination } & \multicolumn{2}{|c|}{ MGT } & \multicolumn{2}{|c|}{ Germination } & \multicolumn{2}{|c|}{ MGT } \\
\hline & & $\mathrm{F}$ & $\mathrm{P}$ & $\mathrm{F}$ & $\mathrm{P}$ & $\mathrm{F}$ & $\mathrm{P}$ & $\mathrm{F}$ & $\mathrm{P}$ \\
\hline Seed lot $(S)$ & 1 & 6.2 & 0.0139 & 0.5 & 0.4831 & 278.8 & 0.0001 & 1.7 & 0.1939 \\
\hline Moisture content (M) & 1 & 66.0 & 0.0001 & 0.2 & 0.6272 & 63.4 & 0.0001 & 0.2 & 0.6436 \\
\hline Priming duration $(\mathrm{P})$ & 4 & 26.7 & 0.0001 & 172.8 & 0.0001 & 25.1 & 0.0001 & 2.3 & 0.0586 \\
\hline Chilling (C) & 2 & 567.0 & 0.0001 & 127.3 & 0.0001 & 650.9 & 0.0001 & 2542.8 & 0.0001 \\
\hline $\mathrm{S} \times \mathrm{M}$ & 1 & 3.4 & 0.0654 & 2.13 & 0.1465 & 14.1 & 0.0002 & 0.0 & 0.9655 \\
\hline $\mathrm{S} \times \mathrm{C}$ & 2 & 21.7 & 0.0001 & 17.7 & 0.0001 & 69.5 & 0.0001 & 0.9 & 0.4227 \\
\hline $\mathrm{S} \times \mathrm{P}$ & 4 & 0.7 & 0.6186 & 13.5 & 0.0001 & 0.5 & 0.0001 & 0.2 & 0.9523 \\
\hline $\mathrm{M} \times \mathrm{P}$ & 4 & 36.7 & 0.0001 & 173.8 & 0.0001 & 15.0 & 0.0001 & 2.7 & 0.0347 \\
\hline $\mathrm{M} \times \mathrm{C}$ & 2 & 315.2 & 0.0001 & 487.3 & 0.0001 & 208.6 & 0.0001 & 101.6 & 0.0001 \\
\hline $\mathrm{C} \times \mathrm{P}$ & 8 & 15.9 & 0.0001 & 224.1 & 0.0001 & 12.5 & 0.0001 & 103.6 & 0.0001 \\
\hline $\mathrm{S} \times \mathrm{M} \times \mathrm{C}$ & 2 & 2.8 & 0.0667 & 17.3 & 0.0001 & 13.8 & 0.0001 & 0.2 & 0.8201 \\
\hline $\mathrm{S} \times \mathrm{M} \times \mathrm{P}$ & 4 & 0.4 & 0.7978 & 4.4 & 0.001 & 3.3 & 0.013 & 0.1 & 0.9682 \\
\hline $\mathrm{S} \times \mathrm{C} \times \mathrm{P}$ & 8 & 1.5 & 0.1738 & 5.4 & 0.0001 & 2.9 & 0.0043 & 0.1 & 0.9991 \\
\hline $\mathrm{M} \times \mathrm{C} \times \mathrm{P}$ & 8 & 14.9 & 0.0001 & 188.5 & 0.0001 & 13.1 & 0.0001 & 112.3 & 0.0001 \\
\hline $\mathrm{S} \times \mathrm{M} \times \mathrm{C} \times \mathrm{P}$ & 8 & 2.0 & 0.0505 & 3.6 & 0.0006 & 1.8 & 0.0768 & 0.1 & 0.9995 \\
\hline Error & 180 & & & & & & & & \\
\hline Total & 239 & & & & & & & & \\
\hline
\end{tabular}

response being greatest in the FI seeds. For the FI seeds given 30 days chilling, MGT declined significantly from 7.6 (no $\mathrm{GA}_{3}$ ) to 3.7 (both $\mathrm{GA}_{3}$ concentrations) in alder, and from 7.7 (no $\left.\mathrm{GA}_{3}\right)$ to $4.4\left(100 \mathrm{ppm} \mathrm{GA}_{3}\right)$ and $4.0\left(200 \mathrm{ppm}^{\mathrm{G} \mathrm{A}_{3}}\right)$ in birch. The equivalent values for the TMC seeds were 8.0, 6.2 and 5.9 in alder; and 5.8, 4.9 and 4.6 in birch (decline not significant in birch). $\mathrm{GA}_{3}$ treatment also reduced MGT in the TMC seeds in alder that received 90 or 120 days chilling. For example in TMC seeds in alder, MGT declined significantly from 5.3 (no $\mathrm{GA}_{3}$ ) to 3.1 (both $\mathrm{GA}_{3}$ concentrations) for seeds that received 120 days chilling. The effect of $\mathrm{GA}_{3}$ was small or negligible in all other cases.

\subsection{Experiment 2. Priming}

While PEG prevented premature germination in the FI seeds, the germination response was similar for seeds treated with or without PEG for 0, 4 or 7 days (common duration treatments). The data for seeds treated without PEG only are presented for this reason. Seeds primed without any previous chilling germinated poorly at both seed MC levels, as shown in Table VI for the FI seeds.

Some of the FI seeds of both species germinated prematurely during the 18-week chilling period, but few did so during the 9-week treatment. Some FI seeds also germinated prematurely during priming (Tab. VI), whereas none of the TMC seeds germinated prematurely during chilling and subsequent priming for up to 14 days.
Chilling duration, $\mathrm{MC}$ and their interactions had the largest effect on germination (Tab. V). Priming and its interaction with MC also had a large effect on germination. Many other treatment interactions were also highly significant. The main finding was that priming had no significant effect on germination in the TMC seeds of alder, but short priming periods improved it in the FI seeds in a few cases (Fig. 2). In the FI seeds chilled for nine weeks, two days priming significantly increased germination from $49 \%$ (control) to $63 \%$ in alder and from $19 \%$ (control) to $29 \%$ in birch. Although 7 days priming increased germination in the TMC seeds of birch chilled for 18 weeks, this was not significant. The significant interaction among MC, chilling and priming reflected these trends (Tab. V). Treatment periods longer than 4 days reduced germination in the FI seeds that had been chilled for 18 weeks, declining to zero following 14 days priming. There was a similar trend for seeds chilled for 9 weeks, but the decline was much smaller.

In general, the effect of treatments on MGT mirrored the pattern described for germination (Tab. V). In alder however, the two-way interaction between priming with chilling and priming with seed MC had a more highly significant effect on MGT than on germination. In the TMC seeds of alder chilled for 9 weeks, MGT declined from 9.2 days for seeds that received no priming to 5.4 days for seeds that received 7 days priming (Insets, Fig. 2). The effects of chilling and its interaction with priming and the three-way interaction among MC, chilling and priming were more highly significant for MGT than for germination in both species (Tab. V). In the FI seeds chilled for 9 weeks, MGT declined from 8.2 (no priming) to 3.1 in alder and from 5.2 (no priming) to 2.7 in birch 

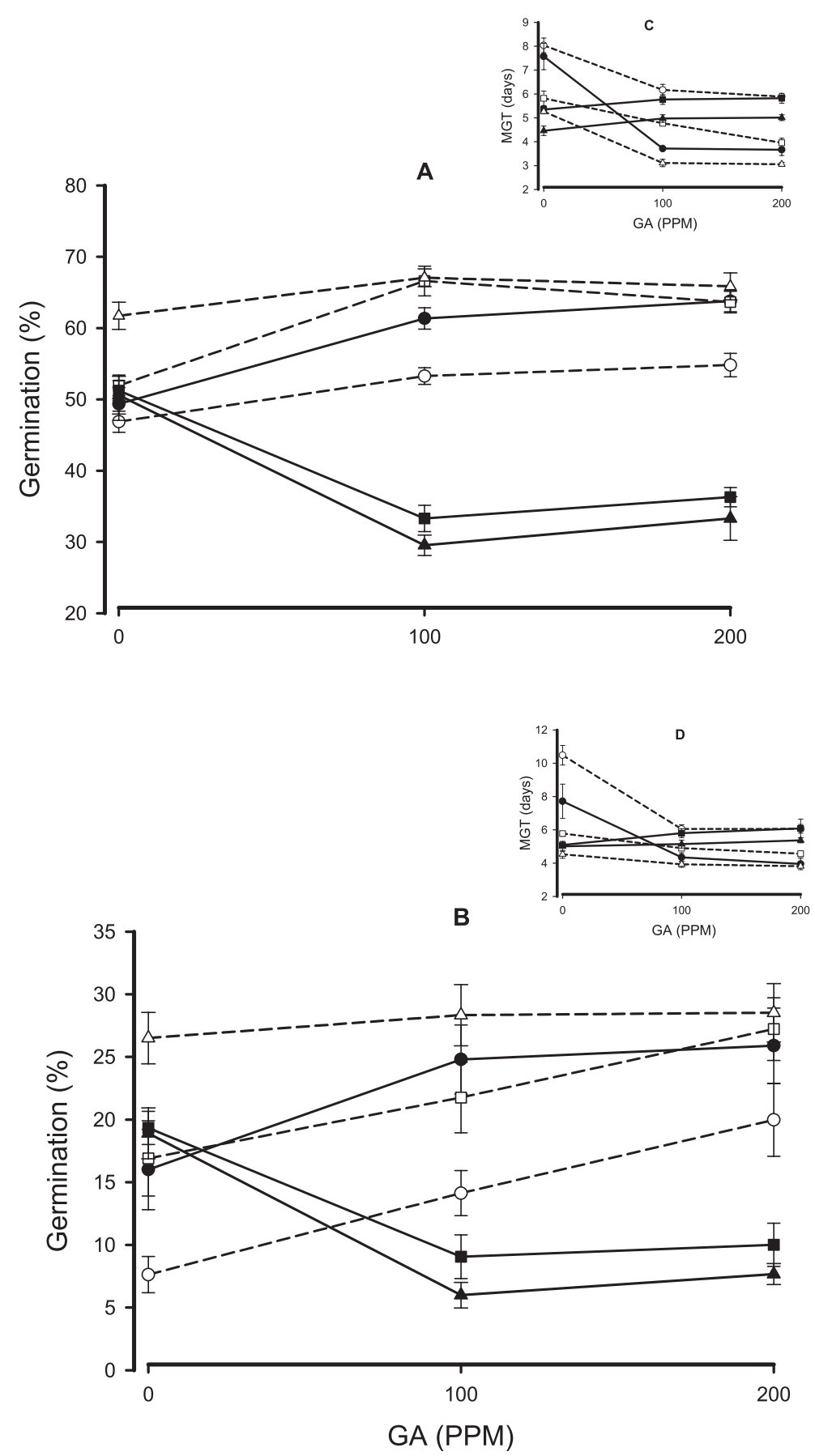

Figure 1. Effect of seed moisture content and chilling duration at different gibberellic acid $\left(\mathrm{GA}_{3}\right)$ concentrations on percentage germination of alder (A) and birch (B) seeds at $15^{\circ} \mathrm{C}$. The insets (C, D) show mean germination time (MGT). Treatments: fully imbibed (continuous lines, full symbols) or target moisture content (discontinuous lines, empty symbols) seeds chilled for 30 (circles), 90 (squares) or 120 days (triangles). The vertical lines are standard errors (some smaller than symbols). 
Table VI. Percentage germination, including or excluding premature germination, in fully imbibed alder and birch seeds in response to chilling and priming.

\begin{tabular}{|c|c|c|c|c|c|c|c|}
\hline & & \multicolumn{6}{|c|}{ Chilling duration (weeks) } \\
\hline & & \multicolumn{2}{|c|}{0} & \multicolumn{2}{|c|}{9} & \multicolumn{2}{|c|}{18} \\
\hline & & \multicolumn{6}{|c|}{ Premature germination included } \\
\hline & & Yes & No & Yes & No & Yes & No \\
\hline \multicolumn{8}{|l|}{ Alder } \\
\hline \multirow{5}{*}{ Priming duration (days) } & 0 & 20.4 & 20.4 & 49.1 & 49.1 & 47.8 & 41.5 \\
\hline & 2 & 24.7 & 24.7 & 63.6 & 62.9 & 43.0 & 36.1 \\
\hline & 4 & 28.1 & 28.1 & 56.2 & 50.4 & 34.0 & 28.4 \\
\hline & 7 & 20.9 & 18.4 & 50.7 & 42.7 & 25.7 & 21.0 \\
\hline & 14 & 27.4 & 22.3 & 40.5 & 34.0 & 5.0 & 0 \\
\hline \multicolumn{8}{|l|}{ Birch } \\
\hline \multirow{5}{*}{ Priming duration (days) } & 0 & 0 & 0 & 18.9 & 18.9 & 20.2 & 15.5 \\
\hline & 2 & 0 & 0 & 29.4 & 28.5 & 17.1 & 10.7 \\
\hline & 4 & 0 & 0 & 26.2 & 22.4 & 11.5 & 7.7 \\
\hline & 7 & 0 & 0 & 23.7 & 17.0 & 9.0 & 5.3 \\
\hline & 14 & 5.3 & 5.3 & 14.3 & 8.7 & 3.6 & 0 \\
\hline
\end{tabular}

following 2 days priming (Insets, Fig. 2). Priming for 14 days greatly increased MGT in the FI seeds that had been chilled for 18 weeks in both species, but the effect (compared with 7 days) was small in other cases. Germination was also very low for seeds given this treatment.

\section{DISCUSSION}

\subsection{Seed lot effects}

Most seed lot differences were small compared with the main effects and were mostly evident only for treatments that resulted in poor germination, suggesting that seed lot effects were not important. In both species, there were some differences between lots in the level of dormancy and quality. The seeds of one lot germinated better than those of the other lot in each species. Seed maturity, weather conditions during seed maturation, genetic factors, handling and storage practices prior to treatment [19] may have caused some of these responses.

\subsection{Experiment 1. Applied $\mathrm{GA}_{3}$}

It appears that $\mathrm{GA}_{3}$ reduced the chilling requirement to release dormancy, but it did not completely compensate for it. $\mathrm{GA}_{3}$ might have enhanced growth promoter levels that helped overcome the effect of the inhibitors (such as ABA), leading to seed dormancy release. Forest tree seeds are genetically highly variable so GA response differences might be expected [44]. Thus, exogenous $\mathrm{GA}_{3}$ may have triggered dormancy release in the fraction of seeds that had not been released from dormancy during chilling. $\mathrm{GA}_{3}$ has been shown to play a key role in dormancy release in the seeds of other broadleaf species, including beech (Fagus sylvatica L.) [7], goldenrain tree (Koelreuteria paniculata Laxm.) [35] and argan tree (Argania spinosa (L.) Skeels) [1]. The results presented here showed that $\mathrm{GA}_{3}$ could be used to shorten the chilling period. However, the response varied greatly with seed MC. A longer period of chilling is needed to release dormancy at lower seed MC [23], so the better response of the TMC seeds to applied $\mathrm{GA}_{3}$ over the longer chilling periods is not surprising (Fig. 1). However, the effect of $\mathrm{GA}_{3}$ treatment may have been confounded with seed MC, although the same amount of $\mathrm{GA}_{3}$ was supplied to both the FI and TMC seeds. It was not possible to determine if more $\mathrm{GA}_{3}$ was available in the TMC than in the FI seeds, although this is unlikely. In addition, De Atrip and O'Reilly [9] previously showed that the seeds of these species maintained good germination potential for up to 36 weeks (252 days) at TMC levels during chilling whereas the FI seeds started to germinate prematurely or deteriorated, consistent with the pattern observed in this study.

Applied $\mathrm{GA}_{3}$ was more effective in improving germination in birch than in alder, especially in the TMC seeds. The larger amount of non-embryonic tissue ${ }^{1}$ in the seeds of alder than birch may have reduced the effectiveness of the applied $\mathrm{GA}_{3}$ ( see [27]). However, the birch seeds may have been more dormant than the alder seeds (as evidenced by their better relative response to chilling without $\mathrm{GA}_{3}$ ), so therefore might respond better to the applied $\mathrm{GA}_{3}$. The sensitivity of seeds to applied $\mathrm{GA}_{3}$ decreases as dormancy is released during chilling [11].

In most cases the lowest concentration (100 ppm) of $\mathrm{GA}_{3}$ used was sufficient to maximize germination speed, but not percentage germination (Fig. 1). This $\mathrm{GA}_{3}$ concentration may have been sufficient to weaken the seed coat [20]. If the seed coat had been weakened by the applied $\mathrm{GA}_{3}$, germination could probably have proceeded quickly thereafter. Higher $\mathrm{GA}_{3}$ concentrations may have been needed to activate the synthesis of proteins and other metabolites required by the embryo for germination [7].

\subsection{Experiment 2. Priming}

Although PEG successfully prevented premature germination in the FI seeds, it did not allow the period of treatment to be extended without causing deterioration (seeds would not germinate when transferred to the optimal conditions of $20 / 30{ }^{\circ} \mathrm{C}$, so they were probably dead). Similarly, the results of research on the seeds of several conifer tree species have shown that PEG provided inconsistent results [17]. In contrast, PEG has been used successfully to prime the seeds of several agricultural and horticultural crop species [2,31].

Priming for 2 days improved both percentage germination and germination speed in the FI seeds of both species that had been chilled for 9 weeks. This improvement was significantly better than could be achieved using the TMC method (without priming) in birch, but not in alder. There is evidence that priming stimulates metabolic activity, such as RNA synthesis, ATP production and enzyme activity $[15,22]$. Perhaps priming 
A
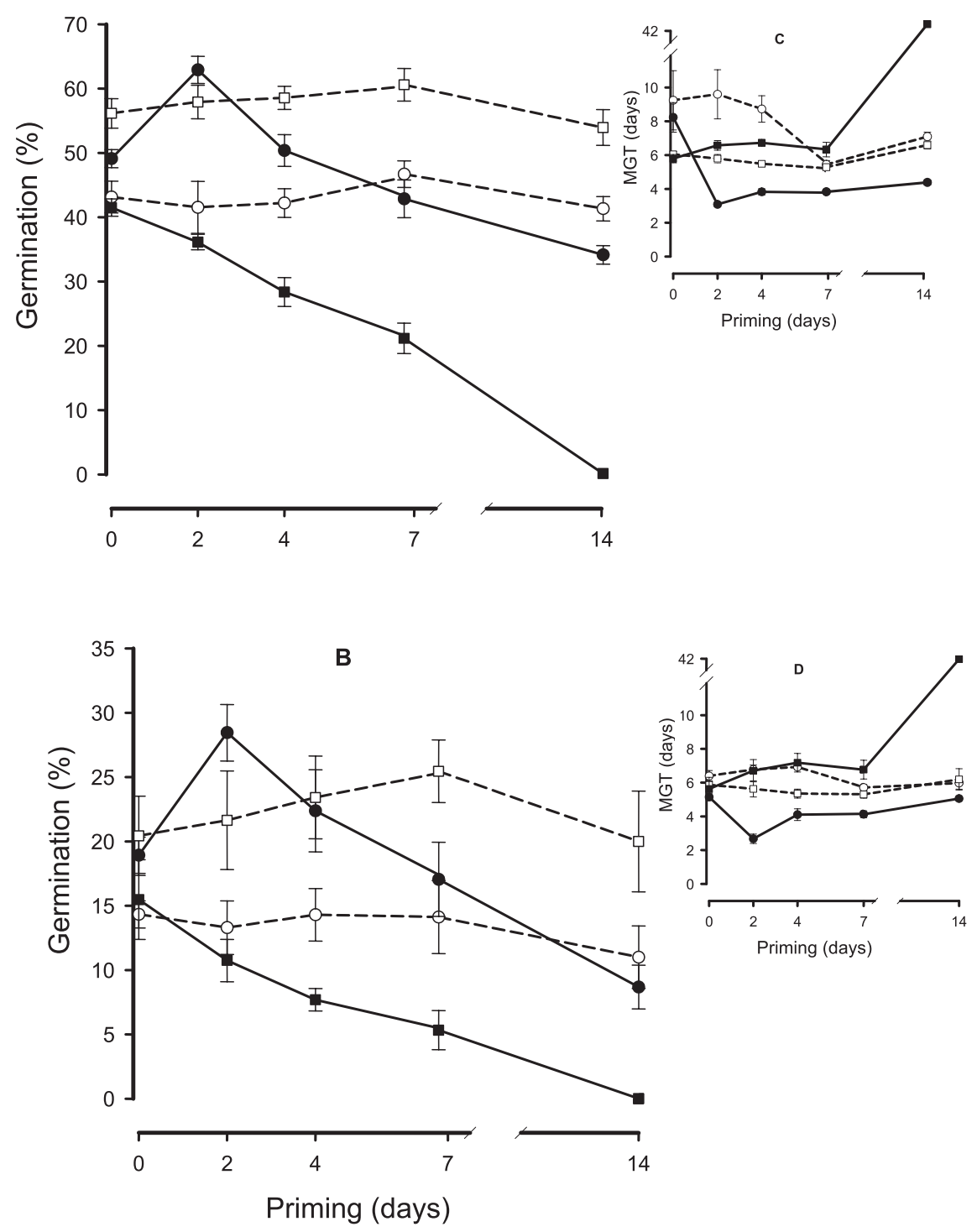

Figure 2. Effect of priming $\left(20^{\circ} \mathrm{C}\right)$ duration on percentage germination of alder $(A)$ and birch $(B)$ seeds at $15^{\circ} \mathrm{C}$. The insets $(\mathrm{C}$, D) show mean germination time (MGT). Treatments: fully imbibed (continuous lines, full symbols) or target moisture content (discontinuous lines, empty symbols) seeds chilled for 30 (circles), 90 (squares) or 120 days (triangles). The vertical lines are standard errors (some smaller than symbols).

stimulated GA metabolism leading to germination, thus inducing a similar response to that described for some $\mathrm{GA}_{3}$ treatments (Fig. 1). Priming may have helped compensate for chilling in the FI seeds leading to a faster rate of dormancy release, as found in Sitka spruce (Picea sitchensis (Bong.) Carr.) [25]. Unlike Sitka spruce however, priming did not enhance germination in seeds that received no prior chilling (Tab. VI), suggesting that it cannot completely compensate for chilling. Priming was less effective in enhancing seed germination in the FI seeds that received the longest chilling period in this study. Similarly $\mathrm{Wu}$ et al. [43] reported that the benefits of priming loblolly pine (Pinus taeda L.) seeds decreased as the length of chilling increased.
In contrast to the FI seeds, priming had a small effect on the germination of the TMC seeds, although 7 days priming significantly increased germination speed in alder. There might have been insufficient moisture in the seeds of both species to allow the TMC seeds to respond to treatment. However, priming of the TMC seeds of several conifer species (30-35\% MC) increased percentage germination and speed of germination $[12,13,21]$. Furthermore, the TMC seeds that received long periods of chilling probably had been fully released from dormancy [9], so might not have responded further to treatment in this study. It is likely that priming stimulated the metabolic processes associated with germination. According to Obroucheva and Antipova [32] the initial activation of 
respiration occurs when seed MC reaches 20-23\%, whereas a MC of at least 55-60\% (similar to the FI levels in alder and birch seeds in this study) is needed before the activation of all major metabolic processes could commence and for germination to occur.

It may be difficult to use the priming method operationally on FI seeds of alder and birch because they begin to germinate prematurely or deteriorate if not sown immediately. However, it is not known if primed seeds can be stored at freezing temperatures or dried back to TMC levels for future use without adversely affecting seed quality and the benefits of pretreatment [34]. It might also have been possible to increase the MC of the TMC seeds to FI levels for priming, but this was not investigated.

The decrease in germination potential in the FI seeds over the final 12 days of priming treatment was probably largely due to seed deterioration as few of them germinated prematurely (Tab. VI). Deterioration was most rapid in seeds that had received 18 weeks chilling (Fig. 2), perhaps because nutrient reserves had been partially depleted during chilling [4,42]. However, additional tests were not carried out to confirm this. It is unlikely that dormancy was re-introduced. Germination at $20 / 30{ }^{\circ} \mathrm{C}$ (data not shown) and at $15^{\circ} \mathrm{C}$ (Fig. 2) was similar. Seed dormancy is broken more effectively using the TMC method than the FI one [9], but the results presented here also show that the TMC seeds still remain sufficiently "quiescent" to withstand the stress of being held for 14 days of priming at $20{ }^{\circ} \mathrm{C}$. Thus the TMC seeds are also likely to better withstand the stresses of handling and storage than the FI seeds, in agreement with earlier findings $[9,10]$. This may not be surprising because seeds are known to deteriorate less rapidly at low MC than at high MC levels [29].

\subsection{Conclusions}

1. $\mathrm{GA}_{3}$ applied before chilling reduced the chilling requirement for dormancy release in alder and birch seeds, but it did not eliminate the requirement for chilling. The effect of applied $\mathrm{GA}_{3}$ was smaller in alder than in birch, probably because the alder seeds were less dormant.

2. Two days of priming at $20{ }^{\circ} \mathrm{C}$ after 12 weeks chilling improved germination in the FI seeds, but more than about four days priming reduced it. In contrast, priming for up to 14 days had a negligible effect on germination in the TMC seeds of both species, regardless of chilling duration used.

Acknowledgements: Coford (Council for Forest Research and Development) and Coillte Teoranta (Irish Forestry Board) funded this research. P. Doody (National Seed Centre, Ballintemple, Ardattin, Co. Carlow, Ireland) provided advice on practical aspects of the research. Dr. J. Connolly and Dr. F. Bannon (Statistics Dept., UCD) assisted with the data analyses.

\section{REFERENCES}

[1] Alouani M., Bani-Aameur F., Argan (Argania spinosa (L.) Skeels) seed germination under nursery conditions: Effect of cold storage, gibberellic acid and mother-tree genotype, Ann. For. Sci. 61 (2004) 191-194.

[2] Bailly C., Benamar A., Corbineau F., Côme D., Antioxidant systems in sunflower (Helianthus annuus L.) seeds as affected by priming, Seed Sci. Res. 10 (2000) 35-42.

[3] Baskin C., Baskin J.M., Seeds: Ecology, biogeography, and evolution of dormancy and germination, Academic Press, San Diego, 1998.

[4] Bergsten U., Removal of dead-filled seeds and invigoration of viable seeds: a review of a seed conditioning concept used on conifers in Sweden, in: Edwards D.G.W. (Ed.), Dormancy and Barriers to Germination, International Symposium IUFRO project group P2.04-00 (Seed problems); 1991, Forestry Canada, Pacific Forestry Centre, Victoria, British Columbia, 1993, pp. 7-15.

[5] Bewley J.D., Seed germination and plant dormancy, Plant Cell 9 (1997) 1055-1066.

[6] Bradbeer J.W., Seed dormancy and germination, Blackie and Son Ltd, Glasgow, 1988.

[7] Calvo A.P., Nicolás P., Nicolás G., Rodríguez D., Evidence of a cross-talk regulation of a GA 20-oxidase (FsGA20ox1) by gibberellins and ethylene during the breaking of dormancy in Fagus sylvatica seeds, Physiol. Plantarum 120 (2004) 623-630.

[8] Coolbear P., Grierson D., Heydecker W., Osmotic pre-sowing treatments and nucleic acid accumulation in tomato seeds (Lycopersicon lycopersicum), Seed Sci. Technol. 8 (1980) 289-303.

[9] De Atrip N., O'Reilly C., Effect of seed moisture content during prechilling on the germination response of alder and birch seeds, Seed Sci. Technol. 33 (2005) 363-373.

[10] De Atrip N., O'Reilly C., The response of prechilled alder and birch seeds to drying, freezing and storage, Can. J. For. Res. 36 (2006) 749-760.

[11] Derkx M.P.M., Karssen C.M., Effects of light and temperature on seed dormancy and gibberellin-stimulated germination in Arabidopsis thaliana: studies with gibberellin-deficient and -insensitive mutants, Physiol. Plantarum 89 (1993) 360-368.

[12] Doody P., O'Reilly C., Effect of moist chilling and priming treatments on the germination of Douglas-fir and noble fir seeds, Seed Sci. Technol. 33 (2005) 63-76.

[13] Downie B., Bergsten U., An invigoration regime for Pinus strobus seeds, Can. J. For. Res. 21 (1991) 1343-1348.

[14] Finch-Savage W.E., Farm woodland tree seed, HRI/MAFF, Wellesbourne, Warwick, 1998.

[15] Fu J.R., Lu X.H., Chen R.Z., Zhang B.Z., Liu Z.S., Ki Z.S., Cai C.Y., Osmoconditioning of peanut (Arachis hypogaea L.) seeds with PEG to improve vigour and some biochemical activities, Seed Sci. Technol. 16 (1988) 197-212.

[16] Fujikura Y., Kraak H.L., Basra A.S., Karssen C.M., Hydropriming, a simple and inexpensive priming method, Seed Sci. Technol. 21 (1993) 639-642.

[17] Gordon A.G., Seed dormancy, seed treatment and seed sowing, in: Gordon A.G. (Ed.), Bulletin 83 "Seed Manual for Forest Trees", HMSO, London, 1992, pp. 116-121.

[18] Gordon A.G., Rowe D.C.F., Seed Manual for ornamental trees and shrubs, Forestry Commission, HMSO, London, 1982.

[19] Gosling P.G., Aldhous J.R., Seed, in: Aldhous J.R., Mason W.L. (Eds.), Forestry Commission Bulletin 111 "Forest nursery practice", HMSO, London, 1994, pp. 66-84. 
[20] Groot S.P.C., Karssen C.M., Gibberellins regulate seed germination in tomato by endosperm weakening: a study with gibberellindeficient mutants, Planta 171 (1987) 525-531.

[21] Hallgren S.W., Effects of osmotic priming using aerated solutions of polyethylene glycol on germination of pine seeds, Ann. Sci. For. 46 (1989) 31-37.

[22] Halmer P., Bewley J.D., A physiological perspective on seed vigour testing, Seed Sci. Technol. 12 (1984) 561-575.

[23] Jensen M., Moisture content controls the effectiveness of dormancy breakage in Abies nordmanniana (Steven) Spach seeds, in: Ellis R.H., Murdoch A.J., Hong T.D. (Eds.), Basic and applied aspects of seed biology, Kluwer Academic Publishers, Dordrecht, 1997, pp. 181-190.

[24] Jinks R.L., Jones S., Gosling P., Improving germination of conifer seed, Forestry British Timber 23 (1994) 24-27.

[25] Jones S.K., Bergsten U., Gosling P.G., A comparison of $5{ }^{\circ} \mathrm{C}$ and $15{ }^{\circ} \mathrm{C}$ as pretreatments for moist, dormant Sitka spruce (Picea sitchensis) seeds, in: Edwards D.G.W. (Ed.), International Symposium IUFRO project group P2.04-00 (Seed problems) Dormancy and Barriers to Germination, IUFRO Project Group P2.04-00, Victoria, British Columbia, 1991, pp. 51-55.

[26] Jones S.K., Gosling P.G., "Target moisture content" prechill overcomes the dormancy of temperature conifers seeds, New For. 8 (1994) 309-321.

[27] Leadem C.L., The role of plant regulators in the germination of forest tree seeds, in: Kossuth S.V., Ross S.D. (Eds.), Hormonal control of tree growth, Martinus Nijhoff Publishers, Dordrecht, 1987, pp. 61-93.

[28] Leubner-Metzger G., Frundt C., Meins F.J., Effects of gibberellins, darkness and osmotica on endosperm rupture and class I B-1,3glucanase induction in tobacco seed germination, Planta 199 (1996) 282-288.

[29] McDonald M.B., Seed deterioration: physiology, repair and assessment, Seed Sci. Technol. 27 (1999) 177-237.

[30] Muller C., Bonnet-Masimbert M., Breaking dormancy before storage: a great improvement to processing of beechnuts, Seed Sci. Technol. 17 (1989) 15-26.

[31] Nascimento W.M., West S.H., Drying during muskmelon (Cucumis melo L.) seed priming and its effects on seed germination and deterioration, Seed Sci. Technol. 28 (2000) 211-215.
[32] Obroucheva N.V., Antipova O.V., The distinct controlling of dormancy release and germination commencement in seeds, in: Viemont J.D., Grabbe J. (Eds.), Dormancy in plants - from whole plant behaviour to cellular control, CABI, Wallingford, 2000, pp. $35-45$.

[33] Pill W.G., Low water potential and presowing germination treatments to improve seed quality, in: Basra A.S. (Ed.), Seed quality - Basic mechanisms and agricultural implications, Food Products Press, New York, 1995, pp. 319-359.

[34] Powell A.A., Seed improvement by selection and invigoration, Scientia Agricola Piracicaba 55 (1998) (special issue) 126-133.

[35] Rehman S., Park I.H., Effect of scarification, GA and chilling on the germination of goldenrain-tree (Koelreuteria paniculata Laxm.) seeds, Sci. Hortic. 85 (2000) 319-324.

[36] SAS Institute Inc., SAS/STAR ${ }^{\circledR}$ User's guide, SAS Institute Inc., Cary, NC, USA, 1989.

[37] Schmidt L., Guide to handling of tropical and subtropical forest seed, Danida Forest Seed Center, Humlebæk, Denmark, 2000.

[38] Suszka B., Cold storage of already after-ripened beech (Fagus silvatica L.) seeds, Arbor. Kornickie 20 (1975) 299-315.

[39] Suszka B., Muller C., Bonnet-Masimbert M., Seeds of forest broadleaves - from harvest to sowing, INRA, Paris, 1996.

[40] Tanaka Y., Brotherton P.J., Dobkowski A., Germination of stratified and non-stratified seeds of red alder at two germination temperatures, New For. 5 (1991) 67-75.

[41] Vegis A., Climatic control of germination, bud break, and dormancy, in: Evans L.T. (Ed.), Environmental control of plant growth, Academic Press, New York, London, 1963, pp. 265-287.

[42] Walters C., Understanding the mechanism of seed deterioration, Seed Sci. Res. 8 (1998) 223-244.

[43] Wu L., Hallgren S.W., Ferris D.M., Conway K.E., Effect of moist chilling and solid matrix priming on germination of loblolly pine (Pinus taeda L.) seeds, New For. 21 (2001) 1-16.

[44] Xia J.H., Kermode A.R., Dormancy of yellow cedar (Chamaecyparis nootkatensis [D. Don] Spach) seeds is effectively terminated by treatment with 1-propanol or nitrate in combination with a warm water soak, gibberellin and moist chilling, Seed Sci. Technol. 28 (2000) 227-240. 